International Journal of Current Advanced Research

ISSN: O: 2319-6475, ISSN: P: 2319 - 6505, Impact Factor: SJIF: 5.995

Available Online at www.journalijcar.org

Volume 6; Issue 5; May 2017; Page No. 3607-3609

DOI: http://dx.doi.org/10.24327/ijcar.2017.3609.0329

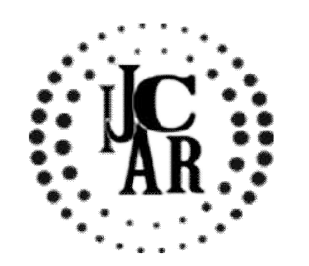

Research Article

\title{
IMMUNOTHERAPY OF CANCER
}

\author{
Swathy. $S^{*}$ and Gheena. $S$
}

Saveetha Dental College

\begin{tabular}{|c|c|}
\hline 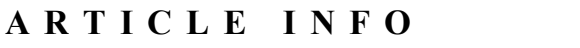 & A B S T R A C T \\
\hline Article History: & $\begin{array}{l}\text { Aim: The aim of the review is to give information about the available immunotherapeutic } \\
\text { approaches for the treatment of cancer. }\end{array}$ \\
\hline $\begin{array}{l}\text { Received in revised form } 12^{\text {th }} \text { March, } 2017 \\
\text { Accepted } 2^{\text {nd }} \text { April, } 2017\end{array}$ & $\begin{array}{l}\text { Objective: This review aims to brief about the mechanisms and efficiency of various types } \\
\text { of immunotherapies that manipulates immune response to treat tumours. }\end{array}$ \\
\hline Published online $28^{\text {th }}$ May, 2017 & $\begin{array}{l}\text { Background: In primary cancer treatment strategies like chemotherapy and radiation } \\
\text { therapy, relapse of tumour is a significant problem. So, alternative therapies that harnesses }\end{array}$ \\
\hline Key words: & more efficient in the near future. \\
\hline $\begin{array}{l}\text { Immunotherapy, Cancer, Tumour, Immunity, } \\
\text { Specific }\end{array}$ & $\begin{array}{l}\text { Reason: Since our understanding of the immune system has increased substantially, there } \\
\text { are a variety of pathways that manipulate the immune system in different manners to } \\
\text { promote anti-tumour responses. This review elaborates on the different immunotherapies } \\
\text { and their mechanisms. }\end{array}$ \\
\hline
\end{tabular}

Copyright $\bigcirc 2017$ Swathy. S and Gheena. S. This is an open access article distributed under the Creative Commons Attribution License, which permits unrestricted use, distribution, and reproduction in any medium, provided the original work is properly cited.

\section{INTRODUCTION}

Neoplasms have antigens against which the host immune system is capable of reacting. Applications of immunisation to treat tumours have come into existance after the definite presence of tumour specific antigen in carcinoma was put forward by Phren and Main in 1957 [1]. However, the concept of tumour immunology came to light when gross in 1943 was able to immunise a mice against sarcoma induced by methyl cholanthrene [2]. It is clinically observed that patients with depressed immune system are more susceptible to cancer [3]. There are several in vitro techniques that identify these antigens which includes immunofluorescence, colony inhibition, complement fixation, immunodiffusion, lymphocyte mediated cytotoxicity, lymphocyte blastogenesis and various radioimmunoassays, indicating that the host responds immunologically to tumour [4]. This implies that cancer cells can be destroyed immologically.

G. A Currie in 1972 classified potential methods of immunotherapy as passive, adoptive and active each of which are further classified into specific and non specific forms of immunotherapy. The classification was given as follows:

- Active specific immunotherapy :Tumour cells, extracts or chemically-modified tumour antigens, Foetal antigens

*Corresponding author: Swathy. S

Saveetha Dental College
- Active non specific immunotherapy :Non-specific stimulants of the immune response BCG,C.parvum,etc.

- Adoptive specific immunotherapy: Xenogeneic or allogeneic sensitized lymphoid cells or extracts

- Adoptive non specific immunotherapy:Normal lymphoid cells allogeneic or xenogeneic.Anti-tumour effect of GVH disease

- Passive specific immunotherapy: Xenogeneic or allogeneic anti-tumour antisera,

- Passive non specific immunotherapy:Non-specific serum factors, Properdin, etc.

- This review gives information on non specific, non specific and adoptive immunotherapy of cancer.

\section{Non Specific Immunotherapy}

Active non specific immunotherapy uses various agents that enhance antibody formation and nonspecifically trigger cellular immunity. There are many non specific immune stimulators that have been identified but the most evaluated are: cornybacterium parvum, levamisole and BCG.

\section{Bcg}

In animals a single injection of BCG results in enhanced humoral immunity, increase in macrophage function, increased resistance to bacterial infection, accelerated homograft rejection and increased resistance to tumor challenge.(6)Intralesional BCG has also been effective in the treatment of intradermal local recurrences of breast carcinoma following a mastectomy.(7). Methe et al in 1969 treated acute 
lymphoblastic lymphoma with $\mathrm{BCG}$ in experimental rodents.BCG was directly given on large skin abrasions. However, the role of BCG is unclear in methe's experiment as his patients were also given allogenic leukemic blast cells along with many other agents including poly i: PolyC Corynebacterium parvum and amantidine. So his clinical success cannot be attributed to the effect of BCG. It can be concluded that BCG along with specific active immunotherapy may provide a synergistic therapeutic effect.(8) It is noticeable that methe was the first to use BCG to treat leukaemia.however,he failed to confirm a clear observation about its effect. Eliber et al used immunotherapy with BCG along with surgical removal of the tumour. His findings suggested that the recurrence rate is minimal when immunotherapy is used as a surgical adjuvant.(9) the use of living BCG may cause generalised disseminated disease in an immune compromised host which may even lead to death of the individual.(10,11,12). This difficulty in using live stimulated interest in using extracts of BCD such as the cord factor and delipidated and deproteinized cell wall.(13) Delipidated and deproteinized cell walls from Mycobacterium tuberculosis H37Ra suspended in 1.25\% mineral oil emulsion cured established tumours in guinea pigs in $33 \%$ of the cases. When the cord factor was used along with Delipidated cell wall, $83 \%$ of the cases showed improvement. The study concluded that the adverse effects of using live BCG can be avoided by using lyophi-lized, killed BCG alone, with $\mathrm{CF}$ in $1 \%$ emulsions of mineral oil or with $\mathrm{BCG}$ and $\mathrm{CF}$ in peanut oil. The percentage of cures was considerably high.

\section{Cornybacterium Parvum And Levamisole}

Cornybacterium parvum, a gram positive anaerobic organism is a strong macrophage stimulator and t cell suppressor. When given intradermally or intralesionally, it is a $\mathrm{t}$ cell stimulator (14). Unlike BCG, C parvum is evaluated as an adjuvant to chemotherapy. A study by Israel and Halpern suggests that the patients who have undergone chemotherapy along with C.parvum had prolonged survival. (15) Levamisole is an antihelminthic which was used for intestinal disorders in man. Its immunotherapeutic effect was discovered accidentally. However, levamisole is less potent when compares to $\mathrm{C}$. Parvum and BCG. $(16,17)$

\section{Specific Immunotherapy}

\section{Activation of Nkt Cells And Nk Cells}

NK cells are components of the innate immune system that play a protective role against some viral infections and tumors $(18,19)$. These functions are achieved by the ability to recognize and lyse target cells $(20,21)$. iNKT cell activation by soluble -GalCer, leads to rapid activation of other immune cells,including NK cells, which express CD69, secrete IFN- , become more cytotoxic, and proliferate (22). The DC-GalCer response, as assessed by the number of IFN-secreting iNKT cells, was much stronger and prolonged than that obtained with soluble -GalCer (23) intravenous delivery of a soluble antigen together with the synthetic CD1d-binding glycolipid -GalCer can lead to in vivo activation of NKT cells and induction of anti tumor T-cell immunity.(24)

\section{Activation of Dentiric Cells}

Dendritic cells (DCs) are bone marrow-derived antigen presenting cells (APCs) that play an important role in the induction and regulation of immune responses. It has been proposed that the manipulation of DCs as a "natural" vaccine adjuvant may prove to be a particularly effective way to stimulate anti tumor immunity. $(25,26)$ The most common approach to using DCs for vaccines is preparing large numbers of autologous mature MDCs ex vivo, load them with antigens, and then injecting them back into the subject $(27,28)$ Three general methods have been described for preparation of the dentritic cells (1) differentiating DCs from leukapheresisderived monocytes with GM-CSF and IL-4105,(29) (the most popular approach; IL-13 has been used by some groups in place of IL-4), (2) GM-CSF and TNF-mediated differentiation of CD34hematopoietic progenitor cells into mixtures of interstitial DCs and Langerhans cells107(30)(Flt3L or stem cell factor may be added to expand DC progenitors, and differentiation may be skewed toward Langerhans cells by adding TGFto the culture(31), or (3) directly isolating DCs from leukapheresis products by density gradient centrifugation (32) or with commercially available closed systems that use immunomagnetic beads.

\section{Carbohydrate Vaccines}

Carbohydrate antigens can be categorized into two major groups: "(i) glycolipids such as GM2, GD2, GD3, and fucosyl GM1 (gangliosides), and Lewis y (Le y ) and globo $\mathrm{H}$ (neutralglycolipids); and (ii) glycoproteins such as the mucinrelated epitopes Tn (GalNAc $\alpha$-O-Ser/Thr), TF (ThomsenFriedenreich,Gal $\beta 1 \rightarrow$ 3GalNAc $\alpha-\mathrm{O}-\mathrm{Ser} / \mathrm{Thr})$ and STn (NeuAc $\alpha 2 \rightarrow$ 6GalNAc $\alpha$-O-Ser/Thr)". Natural and vaccine-induced antibodies againstGM2 and STn have been detected in patients with cancer, and have been associated with prolonged disease-free periods and overall survival. (33) so, these antigens specifically kills the tumour cells.

Cancer carbohydrate antigens such as gangliosides (GM2, GD2, GD3, 9-O-acetyl GD3 and fucosyl GM1), neutral glycolipids (Ley and globo $\mathrm{H}$ ), and mucin related epitopes (TF, Tn, and STn), are suitable targets for both active and passive immunotherapies because they are over expressed at the cell surface of malignant cells and poorly expressed or not accessible on most normal cells. Conjugate vaccines against GD3, GD2, globo H, Ley and TF have induced antibody responses in $60 \%$ or more of patients. These antibodies can react strongly with the cell surface of antigen-positive cancer cells and are said to be able to mediate complement lysis (34)

\section{Adoptive Immunotherapy}

Adoptive immunotherapy is the transfer of lymphoid cells with anti tumor reactivity that can mediate anti tumor responses in the host. Several lymphocyte subpopulations may be suitable for use in adoptive immunotherapy. Resting lymphocytes incubated in interleukin-2 (IL-2) give rise to lymphokine activated killer (LAK) cells that can lyse malignant cells, but not normal cells. In patients with advanced cancers, treatment with high dose IL-2 alone or in combination with LAK cells can mediate the complete or partial regression of cancer in selected patients.(35)

\section{References}

1. Phren RT, Main JM: Immunity to methylcholanthrene induced sarcomas. J Nat'l Cancer Inst 18:769-778, 1957. 
2. Gross L: Intradermal immunization of $\mathrm{C} 3 \mathrm{H}$ mice against a sarcoma that originated in an animal of the same line. Cancer Res 3:326-333, 1943

3. Gatti RA, Good RA: Occurrence of malignancy in immunodeficiency diseases-A literature review. Cancer 28:89-98, 1971

4. Helstrom I, Siogren HO, Warner G: Blocking of cell mediated tumour immunity by sera from patients with growing neoplasms. Int J Cancer 7:225-237, 1971.

5. I McKenzie The Austin Research Institute, Austin Hospital, Heidelberg, Victoria, Australia Breast Cancer Res 2003, 5(Suppl 1):53 (DOI 10.1186/bcr712)

6. Bast RC, Zbar B, Borsos T, et al: BCG and Cancer. $N$ Engl J Med 290:1413-1420, 1974.

7. Rosenberg E, Powell R: Active tumor immunotherapy with BCG: South Med J 66:1359-1363, 197

8. MATHII, G. et al. (1969) Active Immuno therapyfor AcuteLymphoblastic Leukaemia. Lancet,i,697

9. Eilber FR, Morton DL, Holmes EC, et al: Adjuvant immunotherapy with $\mathrm{BCG}$ in treatment of regional lymph node metastases from malignant melanoma. $N$ Engl J Med 294:238, 1976

10. Esterly, J.R., W.Q. Sturner, N.B.Esterly, and D.B.Windhorst.1971. Disseminated BCG in twin boys with presumed chronic granulotatous disease of childhood. Pediatrics 48:141.

11. Mande, R.1968. BCGvaccination. Dawson, London.

12. Sicevic, S.1972. Generalized BCG tuberculosis with fatal course in two sisters.

13. A.Bekierkunst, L.Wang, R.Toubiana, Ande.Lederer, immunotherapy of cancer with nonliving bcg and fractions derived from mycobacteria: Role of Cord Factor(Trehalose-6,6'-Dimycolate) in Tumor Regression, Infection And Immunity, Nov.1974,p.1044-1050

14. Scott MT: Corynebacterium parvum as an immunotherapeutic anticancer agent. Seminars in Oncology 4:367, 1974

15. Israel L, Halpern B: Le Corynebacterium parvum dans les cancers advances. Premiere evaluation de Pactivite therapeutique de cette immunostimuline. Nouv. Presse Med 1:19, 1972

16. Amery $\mathrm{W}$ : Immunopotentiation with Levamisole in resectable bronchogenic carcinoma: A double-blind controlled trial. Br Med J 3:461 464, 1975

17. Chirigos MA, Fuhrman F, Pryor J Jr: Prolongation of chemotherapeutically induced remission of a syngeneic murine leukemia by Levamisole. Cancer Research 35:927, 1975

18. Cerwenka, A., and L.L. Lanier. 2001. Natural killer cells, viruses and cancer. Nat. Rev. Immunol. 1:41-49.

19. Smyth, M.J., Y. Hayakawa, K. Takeda, and H. Yagita. 2002. New aspects of natural-killer cell surveillance and therapy of cancer. Nat. Rev. Cancer. 2:850-861.

20. Street, S.E., E. Cretney, and M.J. Smyth. 2001. Perforin and interferon-gamma activities independently control tumor initiation, growth, and metastasis. Blood. 97:192-197.

21. Street, S.E., Y. Hayakawa, Y. Zhan, A.M. Lew, D. MacGregor, A.M. Jamieson, A. Diefenbach, H. Yagita, D.I. Godfrey, and M.J. Smyth. 2004. Innate immune surveillance of spontaneous B cell lymphomas by natural killer cells and gammadelta T cells. J. Exp. Med. 199:879-884.

22. Carnaud, C., D. Lee, O. Donnars, S.H. Park, A. Beavis, Y. Koezuka, and A. Bendelac. 1999. Cutting edge: cross-talk between cells of the innate immune system: NKT cells rapidly activate NK cells. J. Immunol. 163:4647-4650.

23. Fujii, S.I., K. Shimizu, M. Kronenberg, and R.M. Steinman. 2002. Prolonged IFN-gamma-producing NKT response induced with alphagalactosylceramideloaded DCs. Nat. Immunol. 3:867-874.

24. Hermans IF, Silk JD, Gileadi U, et al. NKT cells enhance CD4 and CD8T cell responses to soluble antigen in vivo through direct interaction with dendritic cells. J Immunol. 2003; 171:51405147.

25. Banchereau J, Briere F, Caux C, et al. Immunobiology of dendritic cells. Annu Rev Immunol. 2000; 18:767811.

26. Ardavin C, Amigorena S, Reis e Sousa C. Dendritic cells: immunobiology and cancer immunotherapy. Immunity. 2004; 20:17-23.

27. Thumann P, Moc I, Humrich J, et al. Antigen loading of dendritic cells with whole tumor cell preparations. $J$ Immunol Methods. 2003; 277:1-16.

28. Schuler-Thurner B, Schultz ES, Berger TG, et al. Rapid induction of tumor-specific type $1 \mathrm{~T}$ helper cells in metastatic melanoma patients by vaccination with mature, cryopreserved, peptide-loaded monocytederived dendritic cells. J Exp Med. 2002; 195:12791288.

29. BenderA, Sapp M, Schuler G, Steinman RM, Bhardwaj N. Improved methods for the generation of dendritic cells from nonproliferating progenitors in human blood. J Immunol Methods. 1996; 196:121-135.

30. Banchereau J, PaluckaAK, Dhodapkar M, et al. Immune and clinical responses in patients with metastatic melanoma to $\mathrm{CD} 34$, progenitorderived dendritic cell vaccine. Cancer Res. 2001; 61:64516458.

31. Strobl H, Bello-Fernandez C, Riedl E, et al. flt3 ligand in cooperation with transforming growth factor-betal potentiates in vitro development of Langerhans-type dendritic cells and allows single-cell dendritic cell cluster formation under serum-free conditions. Blood. 1997;90:14251434

32. Hsu FJ, Benike C, Fagnoni F, et al. Vaccination of patients with B-cell lymphoma using autologous antigen-pulsed dendritic cells. Nat Med. 1996; 2: 5258.

33. Livingston PO, Wong GY, Adluri S et al. Improved survival in stage III melanoma patients with GM2 antibodies: A randomized trial of adjuvant vaccination with GM2 ganglioside. J. Clin. Onc. 1994; 12: 103644.

34. SF Slovin et al., Carbohydrate vaccines as immunotherapy for cancer, Immunology and Cell Biology (2005) 83, 418-428

35. Steven A. Rosenberg, The Development ofNew Immunotherapies for the Treatment of Cancer Using Interleukin-2, Ann. Surg. * August 1988, Volume 208, Number 2 